\title{
Correction to: Coping with climatic shocks: local perspectives from Haiti's rural mountain regions
}

\section{Caroline Staub $^{1} \cdot$ Anne Gilot $^{1} \cdot$ Molene Pierre $^{2} \cdot$ Gerald Murray $^{3}$. Rosalie Koenig ${ }^{1}$}

Published online: 23 September 2020

(C) The Author(s) 2020

\section{Correction to: Population and Environment https://doi.org/10.1007/s11111-020-00351-9}

The article Coping with climatic shocks: local perspectives from Haiti's rural mountain regions, written by Caroline Staub, Anne Gilot, Molene Pierre, Gerald Murray, Rosalie Koenig was originally published electronically on the publisher's internet portal on 12 June 2020 without open access. With the author(s)' decision to opt for Open Choice the copyright of the article changed on September 2020 to (C) The Author(s) 2020 and the article is forthwith distributed under a Creative Commons Attribution 4.0 International License (https://creativecommons.org/licenses/by/4.0/), which permits use, sharing, adaptation, distribution and reproduction in any medium or format, as long as you

The online version of the original article can be found at https://doi.org/10.1007/s11111-020-00351-9

Caroline Staub

carogstaub@ufl.edu

Anne Gilot

agilot@ufl.edu

Molene Pierre

pierremolene@ufl.edu

Gerald Murray

murray@ufl.edu

Rosalie Koenig

rlkoenig@ufl.edu

1 Institute of Food and Agricultural Sciences, University of Florida, Gainesville, FL, USA

2 USAID Feed the Future Appui A la Recherche et au Developpement Agricole Petion-Ville, Pétion-Ville, Haiti

3 Department of Anthropology, University of Florida, Gainesville, FL, USA 
give appropriate credit to the original author(s) and the source, provide a link to the Creative Commons license, and indicate if changes were made.

Open Access This article is licensed under a Creative Commons Attribution 4.0 International License, which permits use, sharing, adaptation, distribution and reproduction in any medium or format, as long as you give appropriate credit to the original author(s) and the source, provide a link to the Creative Commons licence, and indicate if changes were made. The images or other third party material in this article are included in the article's Creative Commons licence, unless indicated otherwise in a credit line to the material. If material is not included in the article's Creative Commons licence and your intended use is not permitted by statutory regulation or exceeds the permitted use, you will need to obtain permission directly from the copyright holder. To view a copy of this licence, visit http://creativecommons.org/licenses/by/4.0/.

Publisher's note Springer Nature remains neutral with regard to jurisdictional claims in published maps and institutional affiliations. 